\title{
The Schizophrenic Solution: Dialectics of Neurosis and Anti-psychiatric Animus in Ralph Ellison's Invisible Man
}

\section{J. BRADFORD CAMPBELL}

Of the many roles St. Philip's Episcopal Church has played in Harlem's modern history, perhaps none is as remarkable as or more improbable than its tenure as the home of the LaFargue Psychiatric Clinic. From 1946 to 1959, the clinic operated literally underground in the basement of St. Philip's parish house, catering to Harlem's racial and economic minorities and offering, in the words of its founder, "the will to survive in a hostile world" ("Psychiatry" 50). On Tuesday and Thursday nights, from six to eight in the evening (though the all-volunteer workforce almost always stayed later), ${ }^{1}$ Harlem's residents would descend into a realm described by Ralph Ellison as a "labyrinth" (Shadow 47) of stairways and hallways to receive treatments and therapies unavailable to them anywhere else. The scene must have been a strange one: outside, a line of the most unlikely candidates for psychotherapy waited for a chance to speak with doctors whose time was more often reserved for the privileged white folk who could pay them; inside, a makeshift waiting room was cobbled together from Sunday school chairs and tables, and the skeleton of a clinic took shape from a row of cubicles stretching the length of a hallway.

Perhaps the only thing more incongruous than the apparatus of psychiatry in the bowels of a church would have been the very existence of a psychiatric clinic in the heart of Harlem, where, following the social logic of the day, there would hardly have been a need for it. For while the inescapably poor and largely African American clientele could and, in accordance with the era's familiar social prejudices, likely would suffer from a kind of vulgar insanity, ${ }^{2}$ psychotherapies of the sort that Dr. Fredric Wertham and his staff sought to provide were considered applicable only to the civilized and sophisticated (read: white and rich) patients who struggled with the more refined neuroses of modernity. ${ }^{3}$

1 According the clinic's first brochure and other early announcements of its existence, services were originally provided on Tuesday and Friday evenings (see The LaFargue Clinic and "LaFargue Clinic Gives Harlem"). A Tuesday and Thursday schedule was later adopted, and as the clinic evolved and gained more volunteers and funding (it was chronically short of both), the Thursday hours were eventually extended to 4:30-8:00, though the staff had long been accustomed to working overtime (see Mosse; "LaFargue Clinic Organization"; "Untitled").

2 Indeed, a newspaper article appearing shortly after the opening of the clinic and discussing the barring of African Americans from mental hospitals ran with the following subtitle: "Psychiatrists Aver: 'They're Crazy Anyway!"” (Curtis 1).

${ }^{3}$ For a more thorough examination of the origins and features of this collaboration between racial and psychiatric politics, see Campbell. 
The LaFargue Clinic was thus a thorough anomaly - the first and, in its own time, the only clinic of its kind, a testament to the urgent need for psychiatric services in Harlem and a sign of the utter absence of them. To exist at all, the LaFargue Clinic, like Ellison's own invisible man, had to go underground; ever since it closed its doors in 1959, it has remained, like Brother Tod Clifton, curiously outside history. I draw attention to it here, though, not simply to plug a historical hole or to recover a forgotten institutional pioneer but to consider the implications of its singular position at the intersection of the histories of literature and psychiatry. For while Wertham helmed and provided a public face for the clinic, it was cofounded by Richard Wright and was supported to varying degrees by a who'swho of literary icons, including Langston Hughes and Ralph Ellison. Indeed, it is Ellison's 1948 essay on the clinic, "Harlem Is Nowhere," that is largely responsible for its remaining in our memory at all, and we can well imagine what his particular interest in LaFargue might have been. For Ellison, Wright, and others, the clinic was a sorely needed antidote to the psychic crises produced by daily life in Harlem, a city awash in what Wertham called a "free-floating hostility" and the embodiment of what Ellison and Wright viewed as the nation's betrayal of its democratic promises (qtd. in Eversley 446). ${ }^{4}$ But their broader interest in psychiatry - of which their involvement with the clinic was a sign and a partmanifests itself at a crucial moment in American cultural history, one in which certain psychiatric definitions of subjectivity were becoming increasingly imbricated in debates over American national identity.

It is precisely at this moment, Shelly Eversley argues, that the work of these writers "enact[s] a historical turn toward psychology" (447). While I disagree that we witness here the advent of self-conscious black literary engagement with psychiatry, I do think that the relationship between these writers and the clinic offers promising ground and a certain imperative for a fruitful investigation of the broader relationship between literature and psychiatry.

Especially where African American literature is concerned, there has been a general reluctance to approach these categories together or to consider the debts and the contributions that each makes to the other. Two notable exceptions are Claudia Tate's pathbreaking Psychoanalysis and Black Novels (1998) and Anne Anlin Cheng's more recent landmark, The Melancholy of Race (2001), which includes a chapter on Ralph Ellison .5 Each of these studies deftly deploys a psychoanalytic framework to interrogate and elucidate the contours and crises of modern African American subjectivity, but neither proposes to examine how mental illness itself is

\footnotetext{
${ }^{4}$ As Shelly Eversley explains, this betrayal was made all the more immediate for Wright and Ellison by the postwar push to see America as an "exemplary democracy." The nation's future as a proverbial beacon for a new democratic world was jeopardized by its commitment to segregationist policy - a profoundly "unresolved tension" that produced a metaphorical schizophrenia for white Americans (447).

${ }^{5}$ We might also include here, more broadly, Frantz Fanon's seminal work The Wretched of the Earth, the final chapter of which - titled "Colonial War and Mental Disorders"-lays important groundwork for understanding forms of racial oppression as "purveyor[s]" of mental distress (181).
} 
represented in African American literature or how those representations might be implicated in the broader history of psychiatry, of which psychoanalysis (as a clinical and literary-critical practice) is a part. As Mark Micale, Roy Porter, and other historians of psychiatry observe, there are significant lacunae in our narrative of how modern literature engages with twentieth-century models of the mind - a dearth of scholarship that works to understand the nature of aesthetic exchanges with the heterogeneous, polyphonic discourses of psychiatry. ${ }^{6}$ This essay seeks at least in part to redress this oversight.

It is indeed remarkable that a novel like Invisible Man, with its consistent and conspicuous attention to a range of mental illnesses, has for so long elicited so little critical commentary on this point. As Caffilene Allen notes in her study of the significance of Sigmund Freud's Totem and Taboo in the novel, "While Ellison's multidimensional Invisible Man has attracted a great deal of critical attention, not much of it has been psychological" (1). Indeed, though numerous critics make passing reference to Ellison's indebtedness to Freud or the "madcap comedy" of the scene at the Golden Day bar and brothel, none pauses to consider the larger implications of and relationship between representations of neuroses in the text (McSweeney 54). ${ }^{7}$ With the exception of Eversley's work, those studies committed to what Allen calls the psychological features of the novel are largely dated and generally problematic. Selma Fraiberg's and Ellin Horowitz's Freudian analyses of the text date from the early 1960s; while some credence has been given to the former, the latter has been branded "too broad to be helpful," producing "confusion, superficiality, forced parallels, undeveloped points and inconsistency" (Covo 32).

Yet even a relatively more recent study like Allen's is itself ultimately unsatisfying. Though her article claims to be an investigation of the significance of Freud's Totem and Taboo in the novel, it is more accurately an attempt to use Freud's clinical theory as a hermeneutic device. In her attempt to "analyz[e] the events in Invisible Man from Freud's theory developed in Totem and Taboo" (3), Allen does not consider how Ellison employs and negotiates the concepts of Freud's treatise in Invisible Man but rather assumes without question the treatise's validity and appropriateness as an interpretive model. As I later suggest, however, a closer examination of how this novel represents neurosis reveals a radically anti-psychiatric impetus that suspects rather than supports Freud's work in Totem and Taboo and challenges many of the larger tenets of psychoanalysis and psychiatry.

The apparent paucity of critical interest in the psychiatric features of the novel may be symptomatic of a more general silence in African American literary criticism when it comes to issues of psychology. As Tate observes, there has long been a "general absence of psychoanalytic models in black intellectual discourse," which can largely be attributed to a venerable critical tradition that has been hesitant, if not entirely unwilling, to tolerate artistic or critical work that focuses too exclusively "on the inner worlds of black characters" (Psychoanalysis 4-5). She recalls

\footnotetext{
${ }^{6}$ See Micale 7. For an introduction to the field of the history of psychiatry, see Roy Porter and Mark Micale's Discovering the History of Psychiatry.

7 For further examples of the casual treatments of neurosis I discuss here, see Phillip Brian Harper ("To Become") and Robert Butler ("The City").
} 
Granville Hicks's claim in a review of Wright's The Outsider that the protagonist is "not so much a Negro ... as a "psychological man" - as if the two could not possibly go together (qtd. in Tate 4). Underlying all this is the familiar but mistaken assumption that the psychological is somehow not social and, if not social, then certainly not implicated in or useful to projects devoted to "black liberation" (5). Indeed, some fear that psychological investigations may even be "detrimental to black agency," and history suggests that such fears rest upon solid ground (16). One thinks, for example, of how psychology and psychiatry were put into the service of World War I-era "intelligence" testing that, under the aegis of an objective exam designed by "eminent psychologists," sought to establish the mental inferiority and civic unfitness of African Americans (Long 22). ${ }^{8}$ It is perhaps because of fears that such history may be repeated that we witness not only the relative rarity of psychoanalytical models that Tate observes, but a more general lack of critical interest in the ways African American literature engages with the discourses of psychiatry.

All the same, it seems prudent to recognize and remain conscious of the many missteps the study of this engagement might make. As Donald B. Gibson observes, there is a risk in psychological studies of race of reading African Americans as necessarily pathological and biologically destined to suffer. He cites Abram Kardiner and Lionel Ovesey's treatise The Mark of Oppression (1962) as an example: "The Negro, in contrast to the white, is a more unhappy person . . . he suffers more. . . . There are no exceptions to this rule. The final result is a wretched internal life" (qtd. in Gibson 41). The problem here, of course, is that such conceptions reduce African Americans to "walking instance[s] of pathology" (Gibson 41). While Gibson does not deny that there may be a relationship between race and neurosis, he does insist that we at least allow black neurotics the possibility of agency and admit room for the negotiation of psychic stress. This is precisely the stance Ellison adopts in Invisible Man as he attempts to make space for the critical examination of psychiatry in literature.

In the pages that follow, I offer a first step toward illuminating the dynamics of this relationship by reading Ellison's epic Invisible Man as a seminal meeting of the aesthetic with the psychiatric. I propose that throughout the novel, Ellison embraces a dialectical understanding of neurosis that figures it as both disabling and enabling and deploys it as a claim to modernity and a rejection of and retreat from the modern world. The text is prescient in its postmodern playfulness, offering a representation of mental illness detached from its specifically psychiatric or broadly medical moorings that anticipates by more than a decade the radical revisions of Michel Foucault and Thomas Szasz. Yet however playful it may seem, Ellison could hardly be called amused. Committed as he was personally to the goals of the LaFargue Clinic, Invisible Man falls far short of the endorsement or celebration of psychiatry we might expect it to be. Instead the text approaches psychiatry and those who practice it as obstacles to rather than agents of social progress. Deeply suspicious of and subtly hostile toward the larger medical establishment's interest in black minds and bodies, the novel is preoccupied with the 
meanings and possibilities of black neuroses at the same time as it is marked by an antipsychiatric animus that prefigures the revolution the field of psychiatry would witness in the decades after the novel was published.

\section{The Primitivist Logic of Twentieth-Century Psychiatry}

Of course, no textual representation of mental illness or literary engagement with psychiatry is entirely self-contained. Rather, it is inevitably and in staggeringly intricate ways connected to the various discourses - popular, scientific, medical, and otherwise - that seek to condition what mental illness means, to whom it applies, and to whom it belongs. If we are to do anything more than observe as simply interesting or record as merely promising the figures of neurosis we find in a text like Ellison's, we must situate them within the formidably dense and historically specific web of discourses in which they are imbricated. None of these discourses seems more important - none played so crucial a role in underwriting the most widely accepted and circulated understanding of neurosesthan the oft-invoked and profoundly vexed discourse of primitivism.

In the decades since Marianna Torgovnick published her definitive study of primitivism in Gone Primitive (1990), it has become a critical commonplace to understand this discourse as culturally and historically specific (Torgovnick 14). As Tracy McCabe puts it, primitivism, far from monolithic, cannot be "simply labeled as either subversive or supportive of dominant ideology" (475). Rather, it "should be read as a local practice or event that takes on diverse and often contradictory meanings in its various social, historical, and literary contexts" (475). The particular context I am interested in here is one in which the discourse of primitivism intersects with the discipline of psychiatry in the era of Invisible Man. More specifically, I want to illuminate the ways that primitivist assumptions and prejudices worked to create a specific understanding of mental illness that posited blacks as "primitive" and therefore free (and, moreover, incapable) of the supposedly refined and civilized neuroses of modernity.

As Ann duCille observes, in the first half of the twentieth century African Americans were often perceived and portrayed as "a panacea for an overindustrialized society dying from an acute case of modernity" - a free, libidinal people whose "untrammeled sexuality" kept them "shielded from neuroses" (73). ${ }^{9}$ What she alludes to here, of course, is the tired myth of the "happy darky" and the attendant notion that blacks, far from potentially neurotic themselves, could actually serve as a remedy for white neurosis. Ellison brings a version of this attitude to life in Invisible Man in the form of young Emerson, the melancholy white son of an entrepreneur who, while he claims to "want to help" the invisible man (Invisible 187), seems more interested in how the invisible man can help him. As several critics have suggested, ${ }^{10}$ Emerson sees in the narrator an opportunity to gain his

\footnotetext{
${ }^{9}$ Ellison himself notes with disdain this "misjudg[ment]" of "Negro passion," which posits the Negro as the "idealized ... symbol of sensation, of unhampered social and sexual relationships" (Shadow 86).

${ }^{10}$ See, for example, Daniel Y. Kim 320.
} 
own sexual freedom and, we might add, to remedy the "neurosis" he implies he has when he refers to a "difficult session with [his] analyst" (185).

Ellison, in fact, seems keenly sensitive to and aware of the assumptions and stereotypes of primitivism in the novel. They operate, for instance, at the first Brotherhood function the narrator attends when a drunken guest asks him to sing "one of those real good ole Negro work songs" and insists that "all colored people sing" (312). They're apparent, too, in Sybil's "revolting" request for a savage sexual experience with "Brother Taboo" (517). The Trueblood scene demonstrates just how far white society will go to enforce these myths: "The nigguhs up at the school come down to chase me off," but the whites "[told] me not to worry, that they was going to send word up to the school that I was to stay right where I am. ... The white folks took up for me. And the white folks took to coming out here to see us and talk with us . . . and wrote it all down in a book" $(67,53)$. This passage records the very process of making the primitive discursive. After rewarding Trueblood for confirming their expectations (and acting out their own deepest desires), the "white folks" record it all in a book that will no doubt disseminate and perpetuate a familiar primitivist logic.

This is precisely the sort of work that was accomplished by various scientific texts such as Robert Park and E. W. Burgess's 1921 Introduction to the Science of Sociology - a text that Ellison not only read but by which he was profoundly provoked. A passage like this one is typical of the discourse:

The temperament of the Negro, as I conceive it, consists in a few elementary but distinctive characteristics, determined by physical organizations and transmitted biologically. These characteristics manifest themselves in a genial, sunny, and social disposition, in an interest and attachment to external physical things rather than to subjective states and objects of introspection. . . . The Negro is, by natural disposition, neither an intellectual nor an idealist, like the Jew; nor a brooding introspective, like the East Indian. . . . He is primarily an artist, loving life for its own sake. (qtd. in $\operatorname{Kim} 310$ )

The keywords of primitivist discourse that codified blacks as happy primitives emerge in Park and Burgess's portrait of blacks as "sunny," "social," life-loving "artist[s]." Perhaps more telling, though, is the way this passage works to deny blacks any sort of interiority. They are, it is claimed, inherently incapable of "introspection" and naturally immune to "subjective states." In short, they are fundamentally, "biologically" invulnerable to neurosis. ${ }^{11}$

Even venerable psychological treatises like Freud's Totem and Taboo, with its subtitled claim to delineate "some points of agreement between the mental lives of

11 That such notions were thoroughly embedded in the culture and could be reproduced by even the most unlikely sources is apparent when we consider that Park was widely regarded as an icon of progressive racial politics and was intimately involved with the efforts of Booker T. Washington and the Tuskegee Institute. Even Ellison admitted that "American Negroes have benefited greatly" as a result of his work, though according to Kim, Ellison severely condemned the view of blacks offered by Park in the text cited above (311). Also see St. Clair Drake. 
savages and neurotics" (the very construction of the subtitle suggesting that the primitive cannot be neurotic), only end up reiterating by implication this artificial division between nonwhite races and neurosis. It is a remarkably conflicted text that in some instances seems to disrupt the distinction between "primitive" and "civilized" and in others seems only to reinforce it along with the primitivist stereotypes it produces. For instance, early in the treatise Freud writes:

It may begin to dawn on us that the taboos of the savage Polynesians are after all not so remote from us as we were inclined to think at first, that the moral and conventional prohibitions by which we ourselves are governed may have some essential relationship with these primitive taboos and that an explanation of taboo might throw a light upon the obscure origin of our own "categorical imperative." (22)

Even while he continues to employ the we-they dichotomy, Freud works here to deconstruct the primitive-civilized binary by suggesting a continuity between the "savages" and "us" - one that shows that "primitives" are not, after all, as remote from "us" as we were wont to think. Yet seemingly fearful of the implications of his own statement, he no sooner suggests these similarities than he takes them back, noting that any likenesses "may be no more than a matter of externals" (26). Though he elsewhere attempts to locate a thorough kinship between the modern "neurotic" and the "savage," he nevertheless makes sure to note that "the differences between the situation of a savage and of a neurotic are no doubt of sufficient importance to make any exact agreement impossible and to prevent our carrying the comparison to the point of identity in every detail" (31). What Freud suggests here, in other words, is that even while we might find certain similarities between savages and neurotics, the savage must never be confused with the neurotic: true neurosis is, in short, something reserved entirely for the "modern" and the "civilized." It is the psychic consequence of repression that, since "primitive men are . . . uninhibited," they never really experience (161). Freud's and Park's work is just one example of how psychological and sociological texts cooperate to lend scientific credence to the notion that African Americans - constructed as primitive and imagined since at least the time of George Miller Beard as America's native "savage," the "bit of barbarism at our doorsteps"-are shielded from neuroses (Beard 189). ${ }^{12}$ As I later suggest, Ellison's representations of neurosis in Invisible Man clearly engage with and revise these specious assumptions even as those representations work to destabilize the traditional theoretical foundations of mental illness.

Freud's treatise also attempts to identify the source of neurosis, claiming that "the same complex constitutes the nucleus of all neuroses," namely the Oedipal

12 The cooperation of scientific discourses I suggest here is reinforced by Invisible Man's Mary Rambo, who, in an early draft of chapter 11 , describes the authorities who have hospitalized the narrator as "psychiatristses and a socialist or sociologist or something" ("Out" 248). Her conflation here is telling, suggesting that psychiatrists, socialists, and sociologists are all about the same to her, at least insofar as their attempts to subjectify, examine, and reprogram the narrator are concerned. 
complex (157). This complex, which he earlier defines as the "child's relation to his parents, dominated . . by incestuous longings," is for Freud the prime mover of all neuroses (17). As Tate has observed, this is a problematic assumption because it "centers the individual's primary nurturing environment, not the external circumstances that precondition that environment" (Psychoanalysis 16). In short, Freud pays scant attention here to the role that material circumstances like poverty, racism, and oppression play in constituting neurosis, an oversight that explicitly inspired the work of the LaFargue Clinic and that Ellison addresses in Invisible Man.

By depicting primitives as unrepressed and naturally unable to experience the neuroses of "civilization," Freud and Park lend scientific credence to a primitivist discourse that romanticized African Americans as fortunate, happy primitives. Of course, under the guise of celebrating black as "better," this romanticizing reinforces racist stereotypes by denying African Americans a complex subjectivity and envisioning them as misfits of modern culture. More ominously, as Ellison himself notes in "Richard Wright's Blues," this tendency to "impute to Negroes sentiments, attitudes and insights which . . . [they] could not humanly possess" may authorize and justify whites' oppression of them: since society assumes that "Negroes possess the richly human virtues credited to them, then their social position is advantageous and should not be bettered; and, continuing syllogistically, the white individual need feel no guilt over his participation in Negro oppression" (86). There is, then, something profound at stake in Ellison's depiction of insanity in Invisible Man. Insofar as neuroses are equated with the modern, Ellison's suggestion of a fundamental relationship between black racial experience and neurosis will not only work to deactivate the assumptions and prejudices I have been examining but will also stake a claim to modernity, insisting that African Americans are indigenous products of (rather than out of place in) modern civilization.

\section{Madness Unmoored: Negotiable Neurosis and "Confusion" at the Golden Day}

That the "neurotic features" of Ellison's text have for so long been entirely overlooked or dismissed as tangential to the novel's supposedly more central aims seems implausible when we consider that madness, after all, is with us from the beginning, when the narrator recalls with a peculiar fondness his college years in the South:

Many times, here at night, I've closed my eyes and walked along the forbidden road that winds past the girls' dormitories, past the hall with the clock in the tower, its windows warmly aglow ... on down the road with its sloping and turning . . . on to where the road became a bridge over a dry riverbed, tangled with brush and clinging vines; the bridge of rustic logs, made for trysting . . . on up the road, past the buildings, with the southern verandas half-a-city-block long, to the sudden forking, barren of buildings, birds, or grass, where the road turned off to the insane asylum. (34-35) 
expansive verandas of the South, so too does insanity loom as an imminent and everpresent possibility in this novel. From the madness of the Golden Day to the melancholy of young Emerson, the text overflows with the idioms and images of mental distress. From the battle royal to the basement epilogue, the invisible man straddles a fine line between sickness and sanity, and this, after all, would seem to be the import of his follow-up to the passage above: "I always come this far and open my eyes" (35). "This far," of course, is that sudden but somehow not surprising fork in the road of his recollection where, always in the distance, looms the asylum. As if unwilling to choose - or perhaps unwilling to confront a choice that has already been made - he opens his eyes at precisely the point at which he must accept or deny the road to insanity, and in this we find an apt figure for his central struggle in this text. The significance of the passage above is twofold: it marks one of the earliest and more subtle instances of the text's preoccupation with mental matters, and it introduces the fundamental but as yet ambiguous relationship between the narrator and neurosis. It may also hint that if we want to understand anything about invisibility and identity in the text, we must examine how it constructs and represents neurosis, and there is no richer example of the text's interest in this condition than the scene at the Golden Day.

Critics have celebrated Ellison's study of madness at the Golden Day as the comic highlight of the novel. Kerry McSweeney, for instance, labels the scene "a rollicking, madcap comedy - a Marx Brothers - or Goon Show-type entertainment, in which the comedy team is a group of mentally disturbed veterans who are masters of the put-on" (54). Yonka Krasteva notes that the scene "recalls again the tradition of the carnival, with its frivolity and ... violence" (65), and William Lyne suggests that the events constitute the "richest and funniest exchanges in the book" (327). Indeed, this scene is funny, and even the narrator, for whom these events are most serious, "wanted to laugh." But if we read this scene as only a sort of comic relief, we risk overlooking the implications of the most sustained portrait of neurosis in the novel. For the scene at the Golden Day in fact presents a kind of mental illness extricated from the traditional psychiatric boundaries that normally control and circumscribe its meaning. Figured dialectically and in terms that recall an almost Shakespearean understanding of madness, neurosis here is both the terrible consequence of overwhelming psychic stress and a liberating license to speak truth to and about power. It not only works to challenge the primitivist assumption that blacks are somehow "shielded from neuroses" but goes further to redefine the constitutive complex of neuroses as social rather than familial.

It is fitting that the text introduces us to the mad veterans by way of a carceral metaphor: "They straggled down the highway in a loose body ... they looked like a chain gang on its way to make a road" (71). As he does in the hospital scenes that appear elsewhere in the novel (and that I examine later in this essay), Ellison here suggests a curious confusion of black mental illness and criminality. The narrator's observation of the mad vets as something like a chain gang recalls for us his institutional experience after the explosion at the factory that he repeatedly figures as not only prison-like but a reproduction of slavery itself. Certainly beneath the humor of the events at the Golden Day - which itself was once, among other things, a "jailhouse" - there is something more serious afoot (80). 
Despite the narrator's initial suggestion that the madness at the Golden Day might all just be a "game" or "joke," it soon becomes apparent that the frivolity is only the thin overlay of a tragedy lurking beneath $(74,158)$. Laughter turns too quickly to violence, and the vets' mad babble bears too many incisive commentaries to be taken lightly. These are the "returning soldiers," but hardly the sort that W. E. B. Du Bois envisioned as "Soldiers of Democracy" who "return fighting" ("Returning" 5). Rather, they have come back "shellshocked," though Ellison's representation of their neuroses suggests that their condition has little to do with the war (73).

We might note, for instance, that little of what the mad vets say recalls the war or suggests any sort of preoccupation with it. Of course, two characters stand out as exceptions here - the "drum major" at the beginning of the scene who confuses Norton with General Pershing and the man who insists that the "absolute Armistice" will "occur at $5: 30$ " $(72,74)$. More often, though, the mad vets' language alludes to matters closer to home. Consider, for instance, the meeting between two of the vets and Norton:

“Look, Sylvester, it’s Thomas Jefferson!”

"I was just about to say, I've long wanted to discourse with him." ...

"Gentlemen, this man is my grandfather!"

"But he's white, his name's Norton."

"I should know my own grandfather! He's Thomas Jefferson and I'm his grandson-on the 'field-nigger' side," the tall man said.

"Sylvester, I do believe that you're right. I certainly do," he said, staring at Mr.

Norton. "Look at those features. Exactly like yours - from the identical mould." (77-78).

As Lyne observes of this exchange, "Our first impression is that these veterans are indeed shell-shocked, speaking a language with significance only for them" (327). But underneath the veteran's apparently absurd claim is an incisive commentary on one of the more infamous instances in the American history of miscegenation - a story vividly remembered in popular lore but deliberately suppressed or downplayed in official histories and biographies. ${ }^{13}$ The language of madness is thus a mode of social commentary that will later become a mode of social protest when, at the height of excitement following their coup d'état, the narrator observes the vets making "hostile speeches at the top of their voices against the hospital, the state and the universe" (85). Clearly the vets have more on their neurotic minds than the war, so one must look elsewhere to understand the etiology of their madness.

The brief personal histories of the vets offered by the narrator begin to indicate what the source of their neuroses might be: "Many of the men had been doctors,

13 I refer here, of course, to the relationship between Thomas Jefferson and Sally Hemings, a story that was not completely told or thoroughly examined until 1998, with the publication of Annette GordonReed's Thomas Jefferson and Sally Hemings: An American Controversy. For more on the nature of and motives for the suppression of this story throughout history, see GordonReed's recently published followup, The Hemingses of Monticello: An American Family. 
lawyers, teachers, Civil Service workers; there were several cooks, a preacher, a politician, and an artist. One very nutty one had been a psychiatrist" (74). This catalogue of professions suggests that madness is largely a mark of the talented tenth, the black professional class "toward which at various times [the narrator himself] vaguely aspired" (74). We might conclude that the narrator's aspirations - and, by implication, the goals and promises of the black professional class - are brought into ironic relief: upward mobility is figured as a futile and almost laughable journey toward insanity. I would suggest, however, that what we find here is not so much an indictment of the black professional dream as an exposure of the racist social practices that make the fulfillment of that dream impossible. Take, for instance, the wise doctor-veteran's explanation of how he ended up in an asylum:

I returned to save life and was refused. . . Ten men in masks drove me out from the city at midnight and beat me with whips for saving a human life. And I was forced to the utmost degradation because I possessed skilled hands and the belief that my knowledge could bring me dignity—not wealth, only dignity—and other men health!

It is not the vet's dream or "belief" that is criticized or rendered absurd but the concrete forces - the ten men in masks - that prevent him from realizing that dream. The passage suggests that the locus of the problem is not in the vet's naive aspirations but in the racist social practices of the South. This is what makes him sick; the source of his neurosis is rooted in his racial experience.

This vet is hardly an exception to the rule. We also have the example of Burn-side, a vet whose paranoia has a similar root. When an anonymous voice explains, "They caught him trying to change some blood into money," Burnside screams, "I did too! . . . I discovered it and John D. Rockefeller stole the formula from me" (81). The claim is absurd but the implication is clear: his paranoia is rooted in a belief that rich whites are somehow capitalizing on him - that they have "stolen" something from him. And we can be sure they have, though it is something far more valuable than a formula to turn blood into money. ${ }^{14}$ Like the wise vet's sickness described above, Burnside's neurosis is informed by and rooted in his racial experience, and his language, like the language of madness everywhere at the Golden Day, is marked by a commentary on the particular experience of blacks in America.

What we find here, then, is that the neuroses Ellison represents at the Golden Day all find their source in material circumstances, namely, the distinctive social conditions of African American life at the time. Even the sole, sustained portrait of white neurosis in this text seems to conform to this paradigm, suggesting that the psychic consequences of these conditions may not be reserved for

14 The portrait of this vet recalls the insane scholar in Richard Wright's Native Son who "was writing a book on how colored people live and he says somebody stole all the facts he'd found" (343). Madness there too is rooted in the character's confrontation with the racist social dynamics of the United States. 
African Americans alone. Mr. Norton - who otherwise serves as a model of reasoned living and enlightened giving - ends up at the Golden Day in a curious state of delirium that one of the vets knowingly diagnoses as a "case of hysteria" (79). It is, of course, the Trueblood incident that drives Norton to distress, but it is not, as others have argued, because it dramatically confirms his own primitivist assumptions and desires. Rather, Norton becomes "hysterical" because Trueblood exposes for him (as will the wise vet later at the Golden Day) his own complicity in creating and perpetuating the myths of primitivism - a considerable blow to one who earnestly considers the social progress of African Americans a fundamental component of his own "destiny" and a telling suggestion that the unsettling of primitivist assumptions we observe in this text has repercussions for the white psyche as well (94).

In any case - indeed, it would seem in every case-Ellison redefines the constitutive complex of neurosis as social, not familial, and in doing so revises Freud's widely accepted but substantially shortsighted notions. ${ }^{15}$ Of course, in the very act of representing black neurosis, Ellison challenges a discourse of primitivism that sought to construct blacks as biologically invulnerable to mental illness. Challenging the assumption that blacks are somehow "shielded . . . from neuroses," Ellison suggests a fundamental, though certainly not inevitable, connection between race and madness (qtd. in duCille 73).

Invisible Man thus demonstrates what Ellison claims elsewhere - that African Americans are, after all, "full of the tensions of modern man" (Shadow 297) and suffer them more acutely because their social conditions are more oppressive and their access to quality treatment is largely denied. (Recall that "therapy" for the vets is a brothel and "treatment" for the narrator is electroshock identity erasure, while someone like young Emerson, whose "neurosis" is little more than bourgeois ennui, has his own "analyst" [185].) In doing so, Ellison debunks the primitivist insistence that blacks have no interiority and claims for them a complex, modern, American subjectivity.

Unusual Suspects: Sinister Shrinks, Blues Bars, and Anti-psychiatric Animus in Invisible Man

If on one front we see Ellison disrupting psychiatry's hold on the meaning of madness by reimagining its etiology and possibilities, on another he much more directly confronts psychiatry in its human and institutional forms: the psychiatrist and the psychiatric hospital. By examining how Invisible Man represents these figures, we can better understand what was at stake for Ellison in his literary rep-

15 As Eversley notes, Ellison and Wright were very much interested in "turning Freud upside down"- a phrase borrowed from Wright's essay on the LaFargue Clinic, "Psychiatry Comes to Harlem" (qtd. in Eversley 445). However, I'm not convinced that an upside-down Freud is the best metaphor for what Ellison accomplishes. Rather than simply reverse the order of the elements of Freud's psychoanalytic philosophy, Ellison presents a profoundly new interpretive paradigm for mental illness that had much in common with the social psychiatry emerging at the time and embodied in practices of the clinic. 
resentations of madness and develop a fuller appreciation of the contours of his larger antipsychiatric project.

It is hardly a coincidence that Ellison begins his essay on Harlem life, "Harlem Is Nowhere," with a description of the LaFargue Psychiatric Clinic. Its singular presence as the "sole mental clinic" (295) in a veritable city of neurosis testifies to the discriminatory racial politics of psychiatry, while its rhetorically central position in the essay suggests that, for Ellison, if one is to understand anything about "Negro life," one must begin by examining the psychological pressures that condition it. Indeed, Ellison was keenly interested in matters of psychology and race, but while he may have been excited by the possibilities of psychiatry in theory, he seems deeply suspicious of them in practice - at least as we see them practiced in Invisible Man.

Ellison was certainly aware of and conversant with the myriad discourses that sought to fix the meanings of neurosis in the first half of the twentieth century. He was particularly familiar with and intrigued by Freud's work, first encountering it at Tuskegee and then continuing to study it assiduously on his own ${ }^{16}$ As Ellison himself recalls, "I read quite a lot of Freudian psychology, and my first job, a very temporary job, when I came to New York, was to work with Dr. Harry Stack Sullivan. I was his receptionist for a few months, and I also filed [and glanced through] case histories" (Graham and Singh 265). His interest in Freud is also manifest in "Richard Wright's Blues," where he employs Freud's work on dreams to analyze and make sense of Black Boy's protagonist (85). It would be a mistake, however, to read Ellison's employment of Freud as an outright validation of Freud's thinking or of psychoanalysis in general. Though useful enough as an interpretive framework in this instance, Ellison elsewhere seems highly suspicious of psychological theories when translated into the practical understanding and treatment of African American neurosis.

In both the novel itself and a wonderfully rich but generally unexamined version of chapter 11 published separately as "Out of the Hospital and under the Bar," Ellison critiques psychiatry's approach to black neurosis by attacking its institutional counterpart, the mental hospital. Ellison's portrait of the narrator at the factory hospital, for instance, suggests a racist motive behind medical treatments of black mental illness. Though we have no reason to suspect that the narrator would have anything more than physical injuries and a bit of amnesia from the explosion in the factory basement, he is nonetheless being "cured" of a supposed neurosis. As one of the doctors explains, they hope to "produce the results of a prefrontal lobotomy without the negative effects of the knife" (Invisible 236). Clearly there is a dangerous sort of experiment under way that, as another doctor suggests, would never occur if the invisible man were a "New Englander with a Harvard background" (236). His comment alludes to, and seems to take for granted, the racial politics that inform the treatment of mental illness: the black mind is apparently useful as a site of psychological experimentation but hardly worthy of a careful, proven cure. 
Of course, the "cure" they hope to effect here is not, after all, in the interest of the patient but of society. In the language of medicine that Ellison parodies to the point of absurdity, the overeager doctor explains:

You see, instead of severing the prefrontal lobe, a single lobe, that is, we apply pressure in the proper degrees to the major centers of nerve control-our concept is Gestaltand the result is as complete a change of personality as you'll find in your famous fairy-tale cases of criminals transformed into amiable fellows after all that bloody business of a brain operation. (236)

The curative function of medicine is curiously translated to a judicial one here, with the object of treatment not to cure an illness but to convert a supposed criminal. These doctors do not attempt to treat any neurosis the narrator might have but rather seek to engineer an identity that will be more palatable and amenable to the expectations of white society. Certainly the patient will no longer "experience [any] major conflict of motives," but "even better" is the fact that "society will suffer no traumata on his account" (236). It is a white fantasy of total control, brilliant and effective because it is invisible - the result of strategically applied "pressure" that leaves no marks; a quiet rather than a "bloody" sort of violence (236). The electroshock "therapy" the narrator receives is not designed to make him "all better" but literally to make him a "new man" (245), a project that deeply implicates psychiatry in the racial fantasies of an increasingly paranoid America (73, 245).

This critique is even more refined in "Out of the Hospital and under the Bar," which Ellison ultimately excised from the novel for "considerations [of] space" ("Out" 243). As Ellison explains in his headnote to the story, "For those who would care to fit it back into Invisible Man let them start at the point where the explosion occurs in the paint factory, substitute the following happenings, and leave them once the hero is living in Mary's hope" (243). This doesn't quite work, however. Though this early version does follow the narrator through his experiences in a hospital, it does not necessarily proceed from an explosion at a factory. There is, in fact, no mention of an explosion or a factory anywhere in this version (as there is in the novel), nor is the invisible man "checked out" through the factory office as he is in the novel (Invisible 245-49). Instead the narrator in this early version recalls an "illness in the street" and being "carried away in an ambulance" ("Out" 290). Presumably, then, Ellison once had a nervous breakdown in mind for our narrator, and "Out of the Hospital" is a study of what happens to him once he enters the hospital system.

While a few critics have remarked upon this earlier version of the chapter for its notable elaboration of Mary's character, ${ }^{17}$ none has considered how this extended scene in a mental hospital might indicate and bear upon Ellison's interest in black neurosis and its treatment. I would suggest that though this early version differs significantly from the final one in terms of detail, its import is the same: we find

\footnotetext{
${ }^{17}$ See, for instance, Tate's “Notes on the Invisible Women in Ralph Ellison's Invisible Man."
} 
here, but in bolder form, the same indictment of psychiatry we witness in the novel itself.

Notably, the hospital in this early version is much more clearly represented as a psychiatric facility. The narrator is confined to an "iron straight-jacket" in a room where, in Mary's "unscientific" language, "psychiatristses and a socialist or sociologist or something [be] looking at you all the time" ("Out" $247,245,248$ ). He is connected to monitoring equipment by electrodes that recall the shock "therapy" in the novel and is told that he is "ill, very ill" right before an orderly attempts to put him in a straitjacket after he escapes (273). If the straitjackets are not suggestive enough, the most compelling sign of the psychiatric ward - the psychiatrist himself-appears during the narrator's escape. As the narrator roams the bowels of the hospital searching for a way out, he overhears an orderly ask, "Why would he think of coming down here?," to which the doctor replies, "Probably some buried memory guided him. Perhaps this storage basement corresponds to the structure of his mind" (275). The doctor's ignorance of the obvious - that the basement is, in fact, the only place the narrator could go-highlights the ridiculousness of his overly analytical explanations. Ellison's parody of psychoanalytic discourse reduces it to absurdity and offers a direct, if somewhat amusing, criticism of psychiatry.

The narrator offers a significantly less amused indictment. For him, the brand of psychiatry practiced at the hospital is not merely absurd but life-threatening: "I had to leave, for I feared that now that I was becoming adjusted to this machine, they planned to place me in one that was smaller-more severe. I'd probably be killed next time" (250). Indeed, while Ellison does not clarify in this excerpt, as he does in the novel, the aim of the hospital's "cure," we can be sure it is just as ominous. After all, Mary doesn't merely facilitate the narrator's escape, she initiates it, indicating that while she might not know exactly "[w]hy these white folks got [him] in this iron straight-jacket," she knows injustice when she sees it (247). ${ }^{18}$ The narrator will later clarify the nature of this injustice when, during his escape, he screams:

You didn't cure me, you took my energy. That's it, you probably have a hospital full of us, using our energy to run your stupid machinery! What do you care about my name? How'd you get us in here, anyway? With a cold pork chop and a loaf of bread? With a black snake whip, with handcuffs and a log chain? You see, I'm leaving, I'm remembering. Lincoln freed the slaves ... and I'm freeing me. (265)

While the narrator's speech is certainly manic and erratic, it nonetheless levels a serious indictment of the mental hospital's motives for treating African Americans. Realizing that he is likely not a special case, the narrator imagines that the

18 Of course, it is possible that Mary knows more than she admits. It is curious that as soon as she enters the narrator's room (she evidently holds some sort of janitorial position at the hospital that allows her unsupervised access), she begins to help him escape. She never states any motive and she never hesitates; she simply begins to pry open the lid of the box that confines him. 
hospital is full of blacks like him, lured or forced into its confines. There is an echo of the novel's suggestion that blacks are used as guinea pigs to further the work of medical science when the narrator claims that the hospital uses "our" energy to run its machinery. Most important, though, is the narrator's invocation of slavery, a gesture that seems to imply that the mental hospital is little more than a reproduction of an old, familiar system, with straitjackets replacing the chains and electrodes the whips. Cures are hardly the point: as we later learn, the hospital is connected via an underground tunnel to (of all things) a Harlem juke joint that the narrator must pass through to escape (277). The metaphor is richly suggestive, and certainly one of its valences must be the implication that the cool blues of the black bar offer a more valid and valuable "cure" than anything the hospital might have effected.

In any case, what both versions of chapter 11 offer are consistently damning critiques of the relationship between psychiatry and race. There is no LaFargue Psychiatric Clinic anywhere in these pages "reject[ing] all stereotypes" and embracing each patient as a dynamic, "modern" human being ("Harlem" 295). On the contrary, these scenes are laced with primitivist assumptions and stereotypes that translate into malicious programs of social engineering, and worse. These unique "treatments," set aside particularly for blacks, are symptomatic of the more widely held belief in a difference between black and white mental illnesses - a belief the implications of which the novel works strenuously to expose and debunk.

\section{"Health in Division": A Schizophrenic Solution?}

If, for Ellison, psychiatry in its traditional forms offers little hope for (and poses a formidable threat to) the treatment of black mental illness, and if clinics like LaFargue will only ever exist as long as they are invisible, pushed underground, and dependent upon private charity rather than public support, what kinds of options - what sorts of hopesremain? Ellison offers a most improbable answer to this question in the novel by suggesting that "treatment" might not be the point at all. Instead of taking for granted the static, immutable reality of mental illness and imagining a LaFargue-like form of "social psychiatry" to treat it, Ellison ultimately seems to figure neurosis itself as highly negotiable - as something that may act upon as well as be acted upon by the mentally ill. The invisible man himself offers a compelling case in point, and by considering our narrator as inescapably neurotic, I want to suggest a new way of understanding just exactly what he has achieved when he says in the epilogue that he has "come a long way" (576).

That the narrator himself might be a portrait of neurosis is a possibility that critics generally seem to ignore, deny, or dismiss. ${ }^{19}$ Yet I would argue that the nar-

19 Julia Eichelberger, for instance, reads Ellison's novel as an "affirmation of 'infinite possibilities" but does not consider whether or how the narrator's neurosis might mitigate or otherwise condition his achievement (57). Butler recognizes that the narrator was once on a track toward madness but suggests that he escapes it in the end and no longer rides those "hard rails" that lead to the Golden Day (131). Eversley allows that Invisible Man is a text interested in "neurosis" and even a kind of "schizophrenia," but she prefers to map both back onto the reader and 
rator's central struggle in this text is his struggle with insanity. Throughout the novel - or at least from the point he arrives in Harlem ${ }^{20}$ - the narrator seems to be on the verge of madness or, perhaps more accurately, of schizophrenia, with the "threat . . . [of] internal discord" ever present (Invisible 335). He struggles to find "peace and quiet, tranquility" and cries out at one point, "If only all the contradictory voices shouting inside my head would calm down and sing a song in unison, whatever it was I wouldn't care as long as they sang without dissonance" (259). But in his quest to squelch this dissonance, he seems to sink only deeper into it. The breaking point comes after he falls through the manhole at the end of his narrative, where his conversation with his pursuers becomes something like a scene from the Golden Day:

"What's in the brief case?"

"You," I said, suddenly laughing. "What do you think of that?"

"Me."

"All of you," I said.

"You're crazy," he said.

"But I still have you in this brief case!"

"What'd you steal?"

"Can't you see?" I said. "Light a match."

"What the hell's he talking about, Joe?"

"Strike a match, the boogy's nuts."

"Ha! Ha! I've had you in my brief case all the time and you didn't know me then and can't see me now." (565-66)

We might speculate here that the narrator is strategically faking madness, and there would certainly be precedent for such an imposture elsewhere in the novel. In the character Homer A. Barbee's tale of the Founder, we meet the "seemingly demented one" who uses his "surprising knowledge" to help the Founder escape, all the while avoiding suspicion by hiding behind the guise of insanity (a strategy also employed by the "granny" to deter the pursuers) (122). Similarly, in Ellison's earlier version of chapter 11, Mary thinks the narrator is faking madness to "[make] a fool outa them doctors" ("Out" 248). Indeed, while such instances certainly suggest the possibility that the narrator is feigning mental illness strategically, the rest of the novel suggests a more compelling possibility.

Far from supporting the idea that he is faking it, the details in the prologue and epilogue - the narrator's revelation of himself in the present - only seem to confirm his neurosis. At the beginning of his narrative, for instance, he admits

American culture more broadly, turning her (and our) attention away from the possibilities of a veritably neurotic narrator $(448,460)$.

20 Several critics have observed a fundamental relationship between the city and neurosis, including Ellison himself, who suggests in "Richard Wright's Blues" that the urban North has profound implications for the "psychosomatic structure" of blacks (88). On this point, see also Butler, Harper, Hana WirthNesher, and Richard Kostelanetz. 
that the very condition of invisibility is "wearing on the nerves," and this no doubt contributes to his abrupt and violent beating of the anonymous insulting stranger (Invisible 3). His actions here suggest a more fundamental irrationality or "hysteria," which is how the narrator himself puts it at the end of the prologue (14).

The epilogue is even more telling. Here he speaks of a "sickness" and "conflict within" $(575,581)$ and elsewhere of the "darkness" in "my own mind" (579). The contradictions and dissonance that he once begged to escape- those symbols of the chaos and cacophony of madness - he now embraces, recognizing "contradiction" as "[the way] the world moves" and admitting that "ambivalence" is something with which he is well acquainted $(6,10)$. He comes to accept the "contradictory voices," an apt metaphor for the literal schizophrenia he seems to affirm when he claims that "only in division is there true health" $(259,576)$. Yet we do not really get the sense that he has regressed but rather, in his words, has "come a long way" (576). What, then, is the nature of his apparent progress? To answer this question, we must return briefly to the Golden Day.

In the exchange between Norton and the wise doctor-veteran, the latter suggests that madness offers a curious mode of transcendence. Speaking of the mad veterans down below, he says, "Such men are beyond money . . . they know nothing of value" (93). More than just "outside history," the veterans, by virtue of their madness, are outside economy and, in this sense, escape the most fundamental (and most oppressive) force of social order. The invisible man achieves something similar through his neurosis, marked as it is by his embracing of contradiction and his affirmation of multiple voices.

As Georg Simmel notes in "The Metropolis and Mental Life," the hallmark of modern life is a "calculative exactness" that, like "the ideal of natural science," seeks to "transform the world into an arithmetic problem, to fix every part of the world by mathematical formulas" (38). This urge to be exact is engendered by "the money economy" that insists on "certainty in the definition of identities and difference" and "unambiguousness" (37-38). To deny this urge is to submit to insanity, for only by guarding against "discrepancies" and contradictions can the individual maintain his or her mental health (37).

It is significant, then, that discrepancies and contradictions are precisely what the invisible man refuses to guard against any longer. The epilogue is in fact a sustained celebration of ambiguity and ambivalence, with the narrator announcing that he has abandoned his struggle to escape dissonance and now embraces contradiction: "I denounce and defend ... I condemn and affirm, say no and say yes, say yes and say no ... I hate and I love" (Invisible 579-80; emphasis added). The invisible man thus refuses binary constructions of the world that insist things must be one or the other, this or that; he avers instead that things - that he - may be this and that. In doing so, he not only rejects the mandates of economy and thus stands, like the vets at the Golden Day, "beyond money" but also denies, by implication, a venerable prejudice, which, informed and underwritten by the money economy, insists he cannot be both black and neurotic, both African and modern (93).

The revelations and renunciations we witness underground in the epilogue seem even to have implications for the most obstinate and unassailable dichotomy of all - the one that insists upon the total and irrevocable divide between san- 
ity and insanity itself. To the men who are chasing the narrator at the end of the novel and who stand topside on the surface, the narrator's retreat underground appears to be a surefire sign that "the boogy's nuts" (566). Yet it is only ensconced in this subterranean space that the narrator finds the means and the moxie to calmly assess and organize the events of his life into the richly allusive, intricately elaborated narrative we have just read. Thus what appears quite literally on the surface to be a kind of insanity may in fact be read, in the supremely ironic spirit of the novel's final pages, as a gesture toward reason, one that, even if not fully consummated, nonetheless posits a sort of seamlessness between sanity and insanity where before only hard lines existed. The narrator may not fully escape his neurosis - as the vet explained to him long ago, mental illness is often the price to be paid for what he ultimately achieves - but he does negotiate and, to some degree, mitigate it by embracing it. Rather than struggle between the poles of a specious dichotomy, he submits, and thereby finds an ironic sort of "health in division" - a kind of sanity in the acceptance of the "contradictory voices . . . inside [his] head" (259). ${ }^{21}$

But if this qualified sanity amounts to any sort of "achievement," it is a tenuous one at best, and such an apparently neat wrapping up of a subject as exceedingly messy as madness admittedly seems to leave the novel open to the kinds of charges that have been leveled against it by those who insist that the text fails to follow through on any of its "revolutionary" potential. Houston A. Baker, for instance, claims that the novel is "burdened by belief, overwhelmed by excessive literary 'smartness,' [and] afraid to breathe life into its potentially revolutionary cartoons" (6). For Baker, Ellison's book is a political failure, and not just because in general it neglects to realize and animate the radical energy of the black masses, but because in particular (as Baker elsewhere suggests) it fails - and, in Baker's terms, fears - adequately to consider and "authentically" represent the importance of Southern black consciousness in the process of civil rights revolution. Ellison's representation of the South is uninformed; his Southern images and characters are mere caricatures-perhaps what one should expect from an Oklahoma-born "outsider." As Baker concludes, "Ellison's black South, unfortunately, does not transcend the Carver Museum at Tuskegee" (6). ${ }^{22}$

The reading of madness I offer above would seem to lend a new kind of support to this sort of argument, suggesting as it does that the final movement of the novel is inward - a retreat - and that its ultimate "solution" is a frustratingly playful,

21 There may seem to be a potentially problematic irony in suggesting that the narrator ultimately embraces a kind of schizophrenia, given that Ellison once described his fellow Americans as "schizophrenics" for their unwillingness to resolve the conflict between their ideals of democracy and the practice of segregation (Eversley 447). Considered in this light, the schizophrenic "solution" I propose we see at the end of the novel would seem uncomfortably to align the narrator with a tradition of deflection and deferral. As I go on to argue, however, Ellison reconceives schizophrenia as a powerful precondition for meaningful action.

22 While I think we may very well see the South as a source of anxiety in this novel, I am not convinced that Ellison's South can be reduced to mere spectacle, nor do I think he entirely fails to register its importance, if not in the struggle for revolution then at least in the struggle for self-realization, which is for Ellison the precondition of any collective realization. 
even if prescient, deconstruction of neurosis that authorizes and encourages the narrator's "hibernation." Read in this light, the narrator's final embrace of dissonance would be less a radical triumph than a stubborn unwillingness to choose a side and fight for it; it would amount to what Jerry Gaffo Watts has elsewhere identified as the invisible man's psychological emigration from the burdens of a politically engaged existence; it would indeed appear to leave us with a narrator who amounts to little more than a postmodern "cartoon" of a neurotic (an example, no doubt, of Ellison's "excessive literary 'smartness"”).

It seems to me, though, that such readings work only by way of a stubborn pessimism that is, more seriously, the product of a highly selective reading of the text. For the invisible man's final gesture in the novel is not toward disengagement, retreat, and stasis but toward a cryptically articulated but nonetheless inevitable "next phase" (Invisible 576). He affirms repeatedly that the "hibernation is over" (580) and that he is "coming out" (581) - a move that is available to the narrator not in spite of but precisely because of the insight and inspiration he gains from his deliberate acceptance of what he variously refers to as "division," "dissonance," and "diversity." This is the "decision [that] has been made" (581) that the invisible man so obscurely refers to before signing off and "coming out"-it is not a final, comprehensive solution but a productive, creative, and enabling compromise that allows the narrator to imagine and pursue that "next phase."

And it is perhaps no coincidence, after all, that the narrator hints that his next move will likely be south: his "passion to return into that 'heart of darkness' across the Mason-Dixon line" may very well be motivated not only by a desire to return to the site where his own story began but to seek a sort of cure for his "sickness" in what has often been imagined as the supreme geographical locus of sanity: the American South $(579,575)$. Such a turn would affirm the South as a vital and restorative part of the nation, especially for those who might have, as Mary warned they would, let too much of Harlem get in them .23

\section{Works Cited}

Allen, Caffilene. "The World as Possibility: The Significance of Freud's Totem and Taboo in Ellison's Invisible Man." Literature and Psychology 41.1-2 (1995): 1-18.

Baker, Houston A. "Failed Prophet and Falling Stock: Why Ralph Ellison Was Never Avant-Garde." Stanford Humanities Review 7.1 (1999): 4-11.

Beard, George Miller. American Nervousness, Its Causes and Consequences. New York: Putnam, 1881.

Bond, Horace Mann. “What the Army 'Intelligence’ Tests Measured.” Opportunity 2.19 (1924): 197-202.

${ }^{23}$ Of course, one might also argue that this turn toward the South at the end of the novel suggests Ellison's sense of the importance of a Southern black consciousness after all, at least insofar as it intersects with matters of black mental health. 
Busby, Mark. Ralph Ellison. Boston: Twayne, 1991.

Butler, Robert. "The City as Psychological Frontier in Ralph Ellison's Invisible Man and Charles Johnson's Faith and the Good Thing." Hakutani and Butler 123-37.

Campbell, Brad. "The Making of 'American': Race and Nation in Neurasthenic Discourse." History of Psychiatry 18.2 (2007): 157-78.

Cheng, Anne Anlin. The Melancholy of Race: Psychoanalysis, Assimilation, and Hidden Grief. Oxford: Oxford UP, 2001.

Covo, Jacqueline. The Blinking Eye: Ralph Waldo Ellison and His American, French, German, and Italian Critics, 1952-1971. Metuchen: Scarecrow, 1974.

Curtis, Constance. "Mental Hospitals Bar Negroes.” New York Amsterdam News 37.19 (27 Apr. 1946): 1. LaFargue Clinic Records (Box 2, Folder 4). Schomburg Center for Research in Black Culture, New York.

Drake, St. Clair. “The Tuskegee Connection: Booker T. Washington and Robert E. Park.” Society 2.4 (1983): 82-92.

Du Bois, W. E. B. "Returning Soldiers.” The Portable Harlem Renaissance Reader. Ed. David Levering Lewis. New York: Penguin, 1995. 3-5.

duCille, Ann. The Coupling Convention: Sex, Text, and Tradition in Black Women's Fiction. New York: Oxford UP, 1993.

Eichelberger, Julia. Prophets of Recognition: Ideology and the Individual in Novels by Ralph Ellison, Toni Morrison, Saul Bellow, and Eudora Welty. Baton Rouge: Louisiana State UP, 1999.

Ellison, Ralph. "Harlem Is Nowhere." Ellison, Shadow and Act 294-302. —

- - Invisible Man. New York: Vintage, 1995.

- - - "Out of the Hospital and under the Bar." Soon, One Morning: New Writing by American Negroes 1940-1962. Ed. Herbert Hill. New York: Knopf, 1968. 242-90.

- - . "Richard Wright's Blues." Ellison, Shadow and Act 77-

94. - - - Shadow and Act. New York: Vintage, 1972.

Eversley, Shelly. “The Lunatic's Fancy and the Work of Art.” American Literary History 13.3 (2001): 445-68.

Fanon, Frantz. The Wretched of the Earth. Trans. Richard Philcox. New York: Grove, 2004.Freud,

Sigmund. Totem and Taboo. Trans. James Strachey. New York: Norton, 1950.

Gibson, Donald B. "The Harlem Renaissance City: Its Multi-illusionary Dimension." Hakutani and Butler 37-49. 
Gordon-Reed, Annette. The Hemingses of Monticello: An American Family. New York: Norton, 2008. 
. Thomas Jefferson and Sally Hemings: An American Controversy. Charlottesville: U of Virginia P, 1997.

Graham, Maryemma, and Amritjit Singh, eds. Conversations with Ralph Ellison. Jackson: U of Mississippi P, 1995.

Hakutani, Yoshinobu, and Robert Butler, eds. The City in African-American Literature. Madison, NJ: Fairleigh-Dickinson UP, 1995.

Harper, Phillip Brian. “"To Become One and Yet Many': Psychic Fragmentation and Aesthetic Synthesis in Ralph Ellison's Invisible Man.” Black American Literature Forum 23.4 (1989): 681700 .

Kim, Daniel Y. "Invisible Desires: Homoerotic Racism and Its Homophobic Critique in Ralph Ellison's Invisible Man.” Novel: A Forum on Fiction 30.3 (1997): 309-28.

Kostelanetz, Richard. Politics in the African-American Novel: James Weldon Johnson, W. E. B. Du Bois, Richard Wright, and Ralph Ellison. New York: Greenwood, 1991.

Krasteva, Yonka. “Chaos and Pattern in Ellison's Invisible Man.” Southern Literary Journal 30.1 (1997): 55-72.

The LaFargue Clinic: A Mental Hygiene Clinic in and for the Community of Harlem. LaFargue Clinic Records (Box 1, Folder 9). Schomburg Center for Research in Black Culture, New York.

"LaFargue Clinic Gives Harlem Free Expert Psychiatric Aid." New York State Journal of Medicine 46.20 (1946). LaFargue Clinic Records (Box 1, Folder 15). Schomburg Center for Research in Black Culture, New York.

"LaFargue Clinic Organization.” 1 Sept. 1952. LaFargue Clinic Records (Box 1, Folder 5). Schomburg Center for Research in Black Culture, New York.

Long, Howard. "Race and Mental Tests.” Opportunity 1.3 (1923): 22.

Lyne, William. "The Signifying Modernist: Ralph Ellison and the Limits of the Double Consciousness.” PMLA 107.2 (1992): 319-30.

McCabe, Tracy. "The Multifaceted Politics of Primitivism in Harlem Renaissance Writing." Soundings 80.4 (1997): 475-97.

McSweeney, Kerry. Invisible Man: Race and Identity. Boston: Twayne, 1988.

Micale, Mark, ed. The Mind of Modernism: Medicine, Psychology, and the Cultural Arts in Europe and America, 1880-1940. Palo Alto: Stanford UP, 2004.

Mosse, Hilde L. "Child Psychiatry and Social Action.” 1981. LaFargue Clinic Records (Box 2, Folder 1). Schomburg Center for Research in Black Culture, New York.

Porter, Roy, and Mark Micale, eds. Discovering the History of Psychiatry. Oxford: Oxford UP, 1994. 
"Psychiatry in Harlem.” Time 1 Dec. 1947: 50. LaFargue Clinic Records (Box 1, Folder 15). Schomburg Center for Research in Black Culture, New York.

Rampersad, Arnold. Ralph Ellison: A Biography. New York: Knopf, 2007.

Simmel, Georg. "The Metropolis and Mental Life." The Sociology of Georg Simmel. Trans. Kurt H. Wolff. New York: Free Press, 1950. Rpt. in Metropolis: Values in Conflict. Ed. C. E. Elias, James Gillies, and Svend Riemer. Berkeley: Wadsworth, 1969. 35-44.

Tate, Claudia. "Notes on the Invisible Women in Ralph Ellison's Invisible Man." Speaking for You: The Vision of Ralph Ellison. Ed. Kimberly W. Benston. Washington, DC: Howard UP, 1987. 16372.

. Psychoanalysis and Black Novels: Desire and the Protocols of Race. New York: Oxford UP, 1998.

Torgovnick, Marianna. Gone Primitive: Savage Intellects, Modern Lives. Chicago: U of Chicago P, 1990.

[Untitled.] 31 Mar. 1957. LaFargue Clinic Records (Box 1, Folder 1). Schomburg Center for Research in Black Culture, New York.

Watts, Jerry Gaffo. Heroism and the Black Intellectual: Ralph Ellison, Politics, and the AfroAmerican Intellectual Life. Chapel Hill: U of North Carolina P, 1994.

Wertham, Fredric. “A New Hospital in Harlem.” LaFargue Clinic Collection (Box 2, Folder 1). Schomburg Center for Research in Black Culture, New York.

Wirth-Nesher, Hana. City Codes: Reading the Modern Urban Novel. Cambridge: Cambridge UP, 1996.

Wright, Richard. Native Son. New York: Perennial Classics, 1998. 